\title{
The occurrence and spread of Gonyostomum semen (Ehr.) Diesing (Raphidophyceae) in Norwegian lakes
}

\author{
C. H. C. Hagman - A. Ballot - D. Ø. Hjermann • \\ B. Skjelbred $\cdot$ P. Brettum $\cdot$ R. Ptacnik
}

Received: 4 February 2014/Revised: 18 September 2014/Accepted: 19 September 2014/Published online: 4 October 2014

(C) The Author(s) 2014. This article is published with open access at Springerlink.com

\begin{abstract}
The invasive and nuisance microalga Gonyostomum semen has recently expanded its geographical distribution and increased its biomass in Sweden and Finland. Temperatures, total organic carbon (TOC), water colour and phosphorous are main factors suggested as drivers for its success. Already in the 1980s there were indications of the same patterns also in Norway, and in this study we further examine these observations based on the hypotheses that (1) G. semen has continued its increase in abundance in Norway since then, (2) after settling in a lake, G. semen may increase its biomass, provided a simultaneous change in climatic factors. We use existing data from Norwegian monitoring databases for the study and additional water samples to investigate distribution. G. semen was detected by microscopy and quantitative PCR, while trends over time in G. semen biomass and possible explanatory variables were analysed by simple regression. We show that $G$. semen has increased its distribution in Norway since
\end{abstract}

Handling editor: David Philip Hamilton

C. H. C. Hagman $(\bowtie) \cdot$ A. Ballot · D. Ø. Hjermann .

B. Skjelbred · P. Brettum

Norwegian Institute for Water Research, Gaustadallèen

21, 0349 Oslo, Norway

e-mail: cco@niva.no

R. Ptacnik

WasserCluster Lunz, Dr. Carl Kupelwieser Promenade 5, 3293 Lunz am See, Austria the 1980s, geographically and to new lakes. In eight of the nine lakes studied, the proportion of G. semen biomass in lake phytoplankton has increased with time. These changes seem to be explained only to some degree by temperature, TOC, water colour and phosphorous.

Keywords Gonyostomum semen - Raphidophyceae · Invasive phytoplankton $\cdot$ Nuisance algae $\cdot$ Norwegian lake phytoplankton $\cdot$ qPCR

\section{Introduction}

The Raphidophyte Gonyostomum semen (Ehr.) Diesing is a flagellated microalga currently inhabiting freshwaters in Europe, Africa, Asia and North- and South-America (Eloranta \& Räike, 1995). The abundance has recently been increasing in lakes in the temperate zone, especially in Scandinavia, both spreading to new lakes and also increasing in biomass, making it an invasive species (Hongve et al., 1988; Lepistö et al., 1994; Rengefors et al., 2012). In some lakes, G. semen exists in low amounts, and is never found in high abundances or known to cause blooms, while in other lakes it might be the dominant alga over the majority of the growth season, causing frequent blooms from July to September (Pithart \& Pechar, 1997; Brettum \& Andersen, 2005; Haande et al., 2012; Lebret et al., 2012b). Due to these blooms and their 
potential consequences, G. semen is considered to be a problematic and nuisance alga with potential of considerable negative impact for the public and local governments (Rengefors et al., 2012).

Gonyostomum semen is known to cause skin irritation for bathers at several locations in Norway and Sweden, caused by ejections of slime threads from trichocysts (Sörensen, 1954; Bjørndalen \& Løvstad, 1984; Cronberg et al., 1988). Although known from Scandinavia since the nineteenth century (Levander 1894 in (Lepistö et al., 1994)), the reports on blooms and problems for bathers started in Sweden in 1948 when a bathing site lost attractiveness to bathers for years, causing economic consequences for the local community (Sörensen, 1954). The first complaint from bathers in Finland was as late as 1978 (Lepistö et al., 1994), and since 1972 there were reports of Norwegian bathers complaining about itching and discomfort in certain lakes where $G$. semen later has been found to cause frequent blooms (Hongve et al., 1988). The problems have continued in Norway since then (Bjørndalen, 1982; Bjørndalen \& Løvstad, 1984) and have caused several bathing sites to lose attractiveness (Hertzberg et al., 1989) or to need investments to prevent discomfort and skin reactions, such as lakeside showers (personal comment Kjell Olausen, Eidsberg commune, Norway).

G. semen is able to form mass occurrences in lakes and occasionally contributes to more than $98 \%$ of the phytoplankton biomass, potentially causing negative effects on ecosystems, communities and disturbances in the trophic chain (Cronberg et al., 1988; Pithart \& Pechar, 1997; Johansson et al., 2013a). During bloom periods, lower biomass of zooplankton food resources are observed (such as small chrysophytes and chlorophytes) and the assembly of zooplankton taxa differ between bloom and non-bloom lakes (Johansson et al., 2013a). Only some species of zooplankton are known to feed on G. semen ( Lebret et al., 2012a;Johansson et al., 2013b), and negative correlations are found both between large biomasses of $G$. semen and the amount of certain zooplankton grazers such as Daphnia (Bjørndalen, 1982; Findlay et al., 2005) and between Daphnia and G. semen recruitment rate from cysts (Hansson, 1996). Also G. semen causes problems when sampling with nets, caused by the slime ejected from the trichocysts at cell disturbance, and drinking waters may be affected by clogging of filters (Bjørndalen, 1982; Hongve et al., 1988; Berge, 1991; ).
(Eloranta \& Räike, 1995) showed that G. semen is able to perform diurnal vertical migration, taking up phosphorous in deep strata and possibly avoiding grazers during night time, while being in the epilimnion during the day (Salonen \& Rosenberg, 2000). Gonyostomum semen also contains several chloroplasts with chlorophyll $a$ (chl- $a$ ), and is known to form extremely large biomass and correlating chl- $a$ concentrations at lower phosphorous levels than e.g. cyanobacteria (Cronberg et al., 1988; Hongve et al., 1988). This creates problems with classification of waters, for instance for the EU Water Framework Directive where classification is based on both nutrients (among other total phosphorous (TP)), chl- $a$ and total phytoplankton biomass. Special considerations must be taken in order to correct for the relationship between $G$. semen and phosphorous, otherwise biomass and chl- $a$ might give the lake an incorrect bad status. Gonyostomum semen, therefore, has been given a high indicator value in the Phytoplankton Trophic Index (PTI) used in the classification of lakes (Directorate group, Water Framework Directive, 2013).

Gonyostomum semen is originally thought to prefer small, shallow, humic, slightly acidic lakes with brownish colour and oligo-mesotrophic or mesotrophic conditions, but has been found to be present in a wide range of conditions regarding nutrients, $\mathrm{pH}$ and water colour, and also in larger lakes (Cronberg et al., 1988; Hongve et al., 1988; Eloranta \& Räike, 1995; Brettum \& Andersen, 2005). The factors influencing increasing abundance and bloom formation, however, are still not properly understood. Several factors have been suggested as drivers for both, either due to enhanced growth or because of competitive advantage with other phytoplankton species; $\mathrm{pH}$, high temperatures, low light intensity and dark water colour, high DOC concentrations, lysis of competitive phytoplankton and vertical migration either to utilize nutrients or to avoid grazers (Eloranta \& Räike, 1995; Salonen \& Rosenberg, 2000; Findlay et al., 2005; Rengefors et al., 2008). Angeler et al. (2010) could not confirm any correlations with environmental variables when looking at bloom formations, but suggests physiological aspects as recruitment rate of cysts or interactions with other species to be influencing factors. Rengefors et al. (2012), however, found a link between increased abundance of $G$. semen and increased temperature in Swedish lakes during the last decades, but as G. semen also increases within climatic regions, DOC is also 
suspected to be an important driver for the expansion of this algae (Rengefors et al., 2012).

Gonyostomum semen was first reported in Norwegian lakes in 1975 but may have been present much earlier (Hongve et al., 1988). The reason for the late first observation is likely to be a combination of two factors: Firstly, it mainly inhabited lakes which were not the main focus of monitoring, since monitoring was predominately focussed on larger and more eutrophic lakes, and secondly, identification has been difficult because of the disruption of cells when fixed with the most commonly used preservation solutions-Lugol's solution or formalin (Sörensen, 1954; Hongve et al., 1988; Brettum \& Andersen, 2005). In the 1980s, when focus on this alga increased in Norway, most lakes with $G$. semen recordings were found in the county Østfold in the southeast of Norway, bordering Sweden (Hongve et al., 1988). In a study conducted in 1982, 23\% of the investigated lakes in this area had dominating biomass of G. semen (Bjørndalen \& Løvstad, 1984). This pattern of distribution continued into 2001 when the distribution of $G$. semen in Norway was last examined (Brettum \& Andersen, 2005). Already in 1988, Hongve et al. indicated expansion of the G. semen distribution in Norwegian lakes as well as increased abundance in each lake (Hongve et al., 1988), however this study was only conducted in a limited geographical area, thus no proper analysis was ever conducted to systematically check the pattern of spreading. Species invading new habitats can either bloom and disrupt the ecosystem and then adapt or disappear again, or they can exist in low abundances for longer periods and then once the conditions improve, cause blooms and act as invasive species. Which pattern G. semen is following is not yet clear, however, recent studies in Finland and Sweden show that G. semen continues to increase in biomass and cause more frequent blooms, possibly driven by change in climatic factors like temperature, dissolved organic carbon (DOC) and water colour (Trigal et al., 2011; Rengefors et al., 2012). This suggests that this species will have continued to increase in Norway also, as temperature and DOC have increased in Norwegian lakes during the last decades (Hongve et al., 2004), thus likely causing more frequent blooms and greater biomasses. In this study, we therefore aimed to further examine the distribution and any possible expansion of $G$. semen in Norway as well as determining if an increase in the proportion of $G$. semen biomass (hereafter referred to as pGony) of the total lake phytoplankton biomass has occurred. We hypothesize that (1) $G$. semen has continued its increase in abundance in Norway after the 1980s, expanding to new lakes and areas, and (2) though already appearing or settled in a lake, G. semen may still increase its biomass and dominance in the ecosystem, driven by simultaneous changes in climatic factors. We aimed to check for the presence of $G$. semen also in samples not taken during the regular phytoplankton monitoring and also outside the areas where $G$. semen is already known to be present. As part of this examination of distribution, we also wanted to develop a method to detect $G$. semen in samples with genetic methods (quantitative PCR, referred to as qPCR). This will make it possible to examine larger sample volumes without fixation and microscopy, and without the need to visually examine net haul samples crowded with other phytoplankton.

\section{Materials and methods}

Dataset

The Norwegian Institute for Water Research (NIVA) possesses a database (BREPHYTO) containing quantitative phytoplankton data from monitoring and research which began in the 1970s, mainly on Norwegian lakes. This database supplemented with reports obtained from NIVAs report archive, County governments and local authorities constitutes the dataset used as a basis for the current study. The samples in the data material are integrated water samples from the epilimnion, collected during the growth season (May-October) and fixed with Lugol's solution with added acetic acid. The samples were analysed with an inverted microscope according to the Utermöhl method (Utermöhl, 1958), which determine cell number in a known area of a settling chamber. Determination of biomass by formulas on cell shapes have been carried out using the recommendations of Rott (1981), Olrik et al. (1998) and CEN TC230 WG2 TG3: Phytoplankton biomass determination, as cited in (Brettum \& Andersen, 2005). Cell number of the counted area is multiplied with the biomass and a calculation factor to find the biomass per litre water sample, given as $\mathrm{mm}^{3} / 1$ wet weight, equivalent to $\mu \mathrm{g} / \mathrm{l}$. 
Table 1 References for the analysis of each physical and chemical lake parameter used in our dataset

\begin{tabular}{|c|c|}
\hline Parameters & Method reference \\
\hline $\begin{array}{l}\text { Total phosphorous } \\
\text { (TP) }(\mu \mathrm{g} / 1)\end{array}$ & $\begin{array}{l}\text { Norwegian Standard, NS } 4725 \text {. Water } \\
\text { analysis-determination of total } \\
\text { phosphorus-digestion by } \\
\text { peroxodisulphate } 3 \text {. Ed., } 1984 \text {. } \\
\text { Modified by automation of the } \\
\text { determination step }\end{array}$ \\
\hline \multirow[t]{2}{*}{$\begin{array}{l}\text { Total nitrogen, }(\mathrm{TN}) \\
(\mu \mathrm{g} / \mathrm{l})\end{array}$} & $\begin{array}{l}\text { Norwegian Standard, NS } 4745 \text {. Water } \\
\text { analysis-determination of the sum } \\
\text { of nitrite nitrogen and nitrate } \\
\text { nitrogen. } 2 . \text { Ed., 1991. Modified by } \\
\text { automation of the determination }\end{array}$ \\
\hline & $\begin{array}{l}\text { Norwegian Standard, NS } 4743 \text {. Water } \\
\text { analysis-determination of total } \\
\text { nitrogen after oxidation by } \\
\text { peroxodisulphate. } 2 \text {. Ed., } 1993\end{array}$ \\
\hline Colour (mg Pt/l) & $\begin{array}{l}\text { NS } 4787 \text {. Water quality- } \\
\text { determination of colour -method } \\
\text { by spectrophotometric determination } \\
\text { of absorbance at } 410 \mathrm{~nm}\end{array}$ \\
\hline $\begin{array}{l}\text { Total organic carbon, } \\
\text { (TOC) }(\mathrm{mg} / \mathrm{l})\end{array}$ & $\begin{array}{l}\text { NS-ISO 8245: Guidelines for the } \\
\text { determination of total organic } \\
\text { carbon (TOC) and dissolved organic } \\
\text { carbon (DOC) }\end{array}$ \\
\hline
\end{tabular}

All physical and chemical data are extracted from the national monitoring database Vannmiljø (operated by the Norwegian Environment Agency), www. vannmiljo.klif.no and from the database Aquamonitor (operated by NIVA), www.aquamonitor.no. Secchi depth (transparency, $\mathrm{m}$ ) and $\mathrm{pH}$ have been measured in situ, while the remaining parameters have been analysed by accredited laboratories. References for each method are given in Table 1 .

\section{Distribution}

For a wider examination of the current distribution in addition to the existing dataset, samples were collected during July-October 2012 in water bodies not included in phytoplankton monitoring but sampled during other NIVA projects. Some of these samples were integrated samples from the epilimnion (normally $0-4 \mathrm{~m}$ ), while others were sampled at surface by the shore or in the outlet of the lake. These samples were either fixed with Lugol's and analysed in an inverted microscope, examining entire chambers of $25 \mathrm{ml}$ cylinders, and/or concentrated for further genetic analysis, in order to detect $G$. semen in larger water volumes than appropriate by visual examination. The method for this procedure is described below. From this combined dataset, all quantitative G. semen observations were extracted together with metadata (not from additional samples taken in 2012) for the purpose of finding the distribution of $G$. semen as well as examining the distribution and scope of mass occurrences, defined as biomass of $G$. semen $\geq 1,000 \mu \mathrm{g} / \mathrm{l}$ wet weight. To test the first hypothesis, all lakes monitored as well as the number of lakes observed with G. semen during the 10-year time spans of 1988-1997 and 2003-2012 were compared.

\section{DNA extraction}

$150-1,500 \mathrm{ml}$ of lake water samples was filtered in the laboratory through a $25-\mu \mathrm{m}$ plankton mesh and the collected material transferred to $15 \mathrm{ml}$ centrifuge tubes, then centrifuged for $15 \mathrm{~min}$ at $4,200 \times g$ and the pellet and maximum $1.5 \mathrm{ml}$ of supernatant were frozen until DNA extraction.

Cell lysis: The samples were incubated at $98^{\circ} \mathrm{C}$ for $5 \mathrm{~min}$, then centrifuged ( $5 \mathrm{~min}, 16,000 \times g$ ) and the supernatant discarded. $600 \mu \mathrm{l}$ of sodium phosphate buffer (120 mM, pH 8) was added, and this solution was transferred to tubes with approx. $0.5 \mathrm{~g}$ of Zirconium beads (autoclaved; $0.5 \mathrm{~mm}$ ) and $100 \mu \mathrm{l}$ SDS $(25 \%)$ was added. After bead beating $(3 \times 15 \mathrm{~s}$, $6,000 \mathrm{rpm}$, and $6,400 \mathrm{rpm}$ for $30 \mathrm{~s}$ ), in a Precellys 24 bead beater (Bertin, Technologies, Saint-Quentin, France), the samples were centrifuged $(6 \mathrm{~min}$, $13,700 \times g)$. The supernatants were transferred to $2 \mathrm{ml}$ tubes, and $500 \mu \mathrm{l}$ of sodium phosphate buffer was added to the remaining pellets and beads, vortexed strongly and centrifuged again $(6 \mathrm{~min}$, $13,700 \times g)$. Both supernatants were combined and $190 \mu \mathrm{l}$ of lysozyme (700,000 Units/ml TE buffer) was added. After incubation at $37^{\circ} \mathrm{C}$ for $15 \mathrm{~min}, 150 \mu \mathrm{l}$ $25 \%$ SDS and $10 \mu \mathrm{l}$ proteinase $\mathrm{K}$ (600 Units/ml Tris$\mathrm{HCl}$ ) were added, followed by incubation at $60^{\circ} \mathrm{C}$ for $15 \mathrm{~min}$ and gently shaking every $3 \mathrm{~min}$.

Precipitation of proteins: $600 \mu \mathrm{l}$ cold ammonium acetate solution $(7.5 \mathrm{M})$ was added to the samples. The samples were incubated on ice for $5 \mathrm{~min}$ and then centrifuged $\left(8 \mathrm{~min}, 13,700 \times g, 4^{\circ} \mathrm{C}\right)$. The supernatant was collected in new $2 \mathrm{ml}$ tubes.

Isolation of DNA: $700 \mu$ isopropanol was added, and the tubes gently shaken and then centrifuged (60 min, $13,700 \times g)$. After discarding the supernatants, the pellets were washed twice by adding $600 \mu \mathrm{l}$ 
ethanol (80\%) and vortexing for $15 \mathrm{~s}$, then centrifuged (5 min, $16,000 \times g$ ). After removal of the last ethanol, the pellet was dried for $10 \mathrm{~min}$ and then dissolved in $50 \mu \mathrm{l} \mathrm{PCR}$ water. The samples were stored at $-20^{\circ} \mathrm{C}$ or used immediately.

Detection of $G$. semen by quantitative polymerase chain reaction (qPCR)

PCR amplification was performed on a CFX 96 Realtime System (BIORAD, Oslo, Norway) using $2.5 \mu \mathrm{l}$ genomic DNA and $12.5 \mu \mathrm{l}$ mix consisting of $7.5 \mu \mathrm{l}$ SsOFast EvaGreen Supermix with low ROX (BIORAD), $3.6 \mu \mathrm{l}$ HPLC water and $0.7 \mu \mathrm{l}$ each of forward and reverse primers $(10 \mathrm{pmol} / \mu \mathrm{l})$ to a total of $15 \mu \mathrm{l}$ per sample. Primers GONVAC2qF (forward, $5^{\prime}$ GCATTGATTACGTCCCTGC-3') and Gon3qR (reverse, $5^{\prime}$-TAACTTCCCACGGCAAGCTC-3') were designed to be specific on $G$. semen and not any other known European freshwater Raphidophyte. Gonyostomum semen is closest related to Vacuolaria virescens (Figueroa \& Rengefors, 2006; Lebret, 2012) and due to few published sequences from this latter species, two cultures of Vacuolaria virescens from the NIVA Algae Culture Collection (NIVA-1/13, NIVA-2/13) were used as controls to ensure the primers did not detect $V$. virescens. A culture of G. semen (NIVA-2/10) and water samples with known presence of $G$. semen were used for positive controls. The water samples were prepared and DNA extracted as for the unknown samples. All PCR was performed with the following programme: $95^{\circ} \mathrm{C}$ for $3 \mathrm{~min}$, then 40 cycles of $95^{\circ} \mathrm{C}$ for $10 \mathrm{~s}$ and annealing at $60^{\circ} \mathrm{C}$ for $15 \mathrm{~s}$, then melt curve at $65-95^{\circ} \mathrm{C}$ for $5 \mathrm{~s}$. Positive results for $G$. semen presence by qPCR were defined by a clear amplification peak combined with a melt peak above threshold and melt peak temperature identical to the positive controls.

\section{Changes in biomass}

To test the second hypothesis concerning increase in $G$. semen biomass and dominance, nine lakes were chosen from the existing data material. These lakes have been monitored on an irregular basis over at least two decades and they cover a large geographical area (Fig. 1). One criteria used was that each year of monitoring had several months sampled during the growth season, in order for seasonal variations to be accounted for in the statistical analysis, as described below. Also, as $G$. semen biomass is usually greatest from August to September (Brettum \& Andersen, 2005; Johansson et al., 2013a), only years including samples from these months were selected. Seven of the lakes already had $G$. semen observations at the start of the time series (Table 2). The lakes had a wide range of pGony at the start of the time series (first obs., $0-44.2 \%$ yearly average), and had different nutrient levels (TN and TP 458-1208 and 8.7-74.4 $\mu \mathrm{g} / \mathrm{l}$ respectively), TOC content (3.85-15.03 mg/l), colour (28.9-119.2 mg Pt/l), Secchi depth (Secchi, 0.8-4.1 m) and pH (6.20-7.53), as well as altitude (35-215 $\mathrm{m}$ above sea level), size (area, 0.4-84.7 $\mathrm{km}^{2}$ ) and maximum depth (4-71 m, some lakes unknown), as shown in Table 2.

From the dataset, we extracted total phytoplankton biomass, G. semen biomass and proportion of G. semen of the total phytoplankton biomass (pGony), given as percentage. Since the total biomass may have changed in these lakes, we focus mainly on the proportional, rather than the absolute biomass of G. semen, as it is not affected by the change of total phytoplankton biomass. To link potential trends in G. semen to relevant explanatory factors, $\mathrm{TP}, \mathrm{TN}, \mathrm{pH}$, colour, Secchi and TOC were used where sufficient data (at least three non-subsequent years) were available. These data are only used as indicators of possible explanations of changes in pGony, and should therefore not be given significant weight as individual results in this study.

\section{Statistical analysis}

The analysis was performed in $\mathrm{R}$ version 3.0.1 using function $\mathrm{lm}$ (linear modelling). A regression analysis was conducted between each of the investigated parameters and time for each lake individually, as the lakes do not necessarily reveal the same trends, additionally the years of investigation varied between lakes. Seasonal variations were taken into consideration by including Month as a factor. Significance in trends, either increase or decrease in the variables, are defined by $P$ value less than 0.05 .

\section{Results}

Distribution

By 2012, there were observations of G. semen in Norway in a total of 117 lakes, mostly in the south- 
Fig. 1 The nine lakes used in the biomass change study

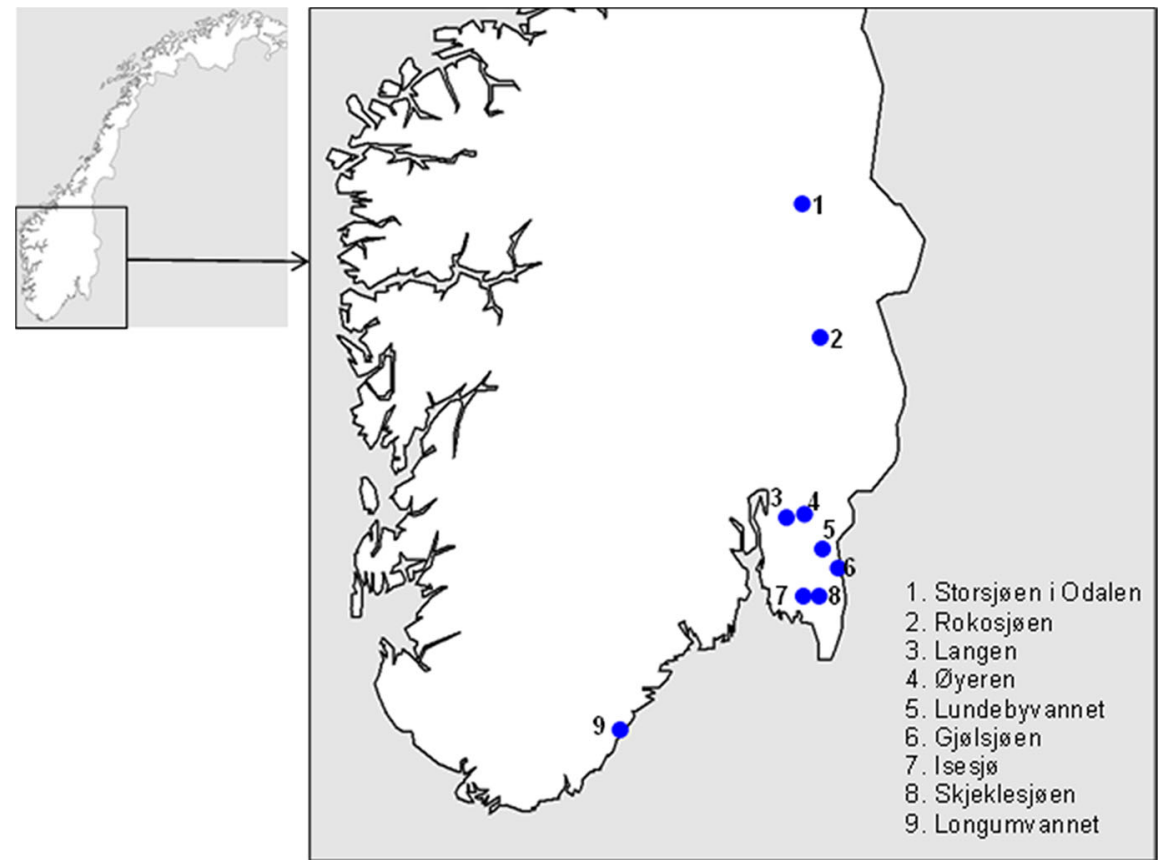

Table 2 Lakes used for the study on changes in biomass, including their characteristics and most recent physical and chemical data (mean of the last three available, subsequent years, exceptions for Gjølsjøen: TOC, Colour, Secchi depth year 1997, pH year 2001, TP and TN average 2007-2008)

\begin{tabular}{|c|c|c|c|c|c|c|c|c|c|c|c|}
\hline Lakes & $\begin{array}{l}\text { Start } \\
\text { (year) }\end{array}$ & $\begin{array}{l}\text { PGony } \\
(\%)\end{array}$ & $\begin{array}{l}\text { Alt. } \\
(\mathrm{m})\end{array}$ & $\begin{array}{l}\text { Area } \\
\left(\mathrm{km}^{2}\right)\end{array}$ & $\begin{array}{l}\text { Max. depth } \\
\text { (m) }\end{array}$ & $\begin{array}{l}\text { TOC } \\
(\mathrm{mg} / \mathrm{l})\end{array}$ & $\begin{array}{l}\text { Colour (mg } \\
\mathrm{Pt} / 1)\end{array}$ & $\begin{array}{l}\text { Secchi } \\
(\mathrm{m})\end{array}$ & $\mathrm{pH}$ & $\begin{array}{l}\mathrm{TP} \\
(\mu \mathrm{g} / \mathrm{l})\end{array}$ & $\begin{array}{l}\mathrm{TN} \\
(\mu \mathrm{g} / 1)\end{array}$ \\
\hline Gjølsjøen & 1988 & 0.1 & 114 & 1.0 & 4 & 4.50 & 94.4 & 0.8 & 7.17 & 74.4 & 1,208 \\
\hline Isesjø & 1988 & 43.0 & 38 & 6.4 & 22 & 10.65 & 79.6 & 1.5 & 7.53 & 21.8 & 657 \\
\hline Langen & 1985 & 10.4 & 126 & 1.5 & 18 & 10.76 & 93.4 & 1.4 & 7.00 & 16.7 & 458 \\
\hline Longumvannet & 1979 & 0.0 & 34.6 & 1.3 & & 4.87 & 28.9 & 4.1 & 7.10 & 8.7 & 468 \\
\hline Lundebyvannet & 1988 & 44.2 & 158 & 0.4 & 5.5 & 13.08 & 119.2 & 1.3 & 6.20 & 27.3 & 612 \\
\hline Rokosjøen & 1988 & 4.4 & 215 & 4.0 & 17 & 15.03 & 108.5 & 3.3 & 6.46 & 11.1 & 495 \\
\hline Skjeklesjøen & 1992 & 22.1 & 112 & 0.7 & & 13.07 & 106.0 & 1.3 & 6.69 & 22.0 & 726 \\
\hline Storsjøen $^{\mathrm{a}}$ & 1987 & 0.7 & 132 & 45.6 & 17 & 7.13 & 67.8 & 3.9 & 6.50 & 10.5 & 458 \\
\hline Øyeren & 1980 & 0.0 & 101 & 84.7 & 71 & 3.85 & 31.8 & 2.5 & 7.30 & 13.8 & 502 \\
\hline
\end{tabular}

'Alt.' gives altitude. The start of the time series for each lake ('Start') and yearly average this year ('pGony') are also given

a Storsjøen in Odalen, referred to as 'Storsjøen'

eastern part of the country (Fig. 2). The single observations made from Stølevatn in the west and Lille Jonsvatn in the middle have not been recently confirmed, but the observations in two lakes in the north (on Vestvågøy island in Lofoten), Farstadvatn and Ostadvatn, were confirmed, thus the northernmost observations are at 68 degrees north. The total of 117 lakes with $G$. semen includes nine out of 65 lakes sampled additionally in July-October 2012, these nine lakes also located in the south-eastern parts of Norway. None of these 65 lakes additionally sampled in the middle or western parts, contained G. semen. Three of the nine lakes with detections of G. semen, Horpestadvatnet, Strandsjøen and Holttjern, were the result of qPCR on larger volumes of filtered water samples.

Between 1988-1997 545 lakes were monitored of which 52 had observations of G. semen during this 
Fig. 2 The current distribution of G. semen in Norway. Triangles for each lake with at least one observation of the algae. Lakes where mass occurrences (biomass $\geq 1,000 \mu \mathrm{g} / \mathrm{l}$ ) have been observed are red. $X$-axis gives longitudes and $y$-axis gives latitudes



period or earlier (Fig. 3a). During the years 2003-2012 G. semen were found in 78 of 322 monitored lakes (Fig. 3b). G. semen was also observed in 16 additional lakes during other years than these two time intervals (Fig. 3b). There were 152 lakes monitored both during 1988-1997 and 2003-2012, with a total of 49 lakes with G. semen. 30 of these lakes had G. semen in both periods, 19 lakes only had G. semen observations after 2003.

\section{Changes in biomass}

The biomass of G. semen has increased according to observation data from the BREPHYTO database, especially after 1990 (data not shown), and 36 (33\%) of all investigated lakes with quantitative phytoplankton analysis had blooms of G. semen at least at one observation, and these are all located in southern and south-eastern parts of Norway (Fig. 2). Of the total of 952 samples with $G$. semen observations in the BREPHYTO database, 144 (15\%) were $\geq 1,000 \mu \mathrm{g} / \mathrm{l}$ and thus defined as mass occurrences (data not shown). Before 1991, 7\% of G. semen observations were mass occurrences, between 1991 and 2000 23\%, and between 2001 and 2012 15\%. During the same timespans, these observations of mass occurrences were located in 8,32 and $41 \%$ of all lakes containing G. semen, respectively. Most of the blooms and peaks in biomass occurred during August and September, only rarely earlier in the growth season and never later (data not shown).

For the selection of nine lakes, there were significant increases $(P<0.05)$ in pGony in eight, only in Isesjø G. semen shows no significant trend with time 


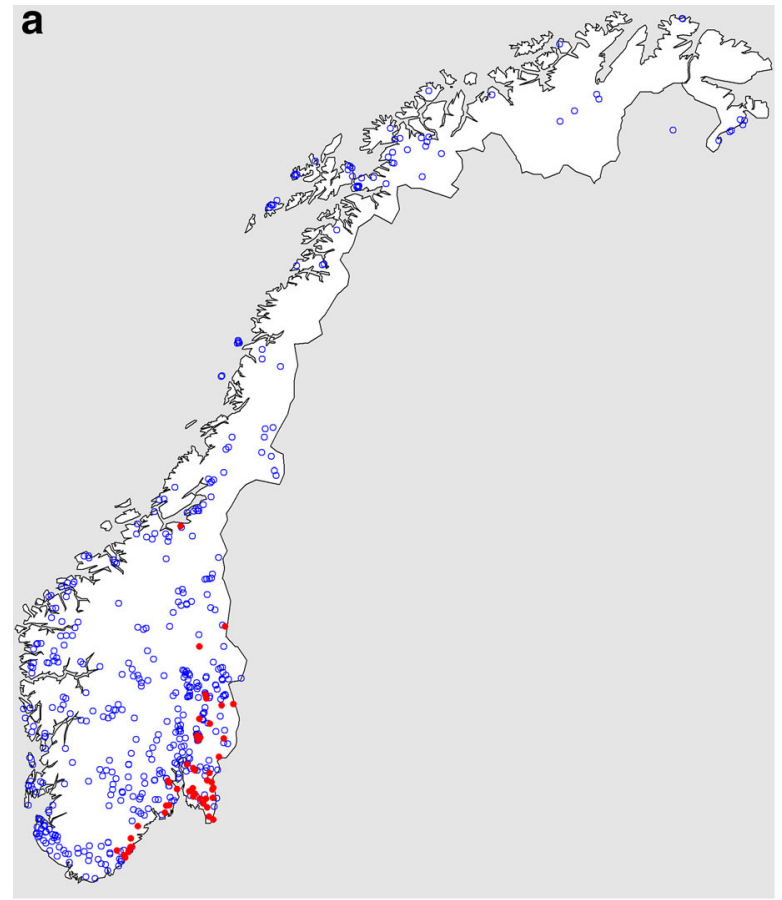

Fig. 3 a Norwegian lakes monitored during 1988-1997 (open, blue circles: no G. semen, filled red circles: observations of $G$. semen). b Norwegian lakes examined during 2003-2012 (open, blue circles: no $G$. semen observed, filled red circles:

(Fig. 4). G. semen biomass increased significantly in seven lakes, the trend was positive but not significant in Lundebyvannet and Rokosjøen (Table 3). The total phytoplankton biomass of the lakes increased significantly in six lakes, and decreased significantly in one lake (Table 3).

Predominately, this increase in pGony has occurred more or less gradually starting sometime after 1990, but in Gjølsjøen, G. semen was absent in 1990s and 2001 and increased to $83.8 \%$ between 2001 and 2007. This lake also had the largest recording of G. semen biomass in this study; 46,794 $\mu \mathrm{g} / 1$ (99.2\%) in September 2007. In Longumvannet, Rokosjøen, Storsjøen in Odalen (referred to as 'Storsjøen') and Øyeren, $G$. semen contributed non-significantly to the phytoplankton biomass in the 1980s and 1990s; however, the yearly average in Øyeren never reached more than $2.5 \%$. In Lundebyvannet, G. semen predominates the phytoplankton community limiting variation in other phytoplankton taxa, with the variation in the total phytoplankton biomass being caused by G. semen alone (data not shown). Additionally, Isesjø has a great

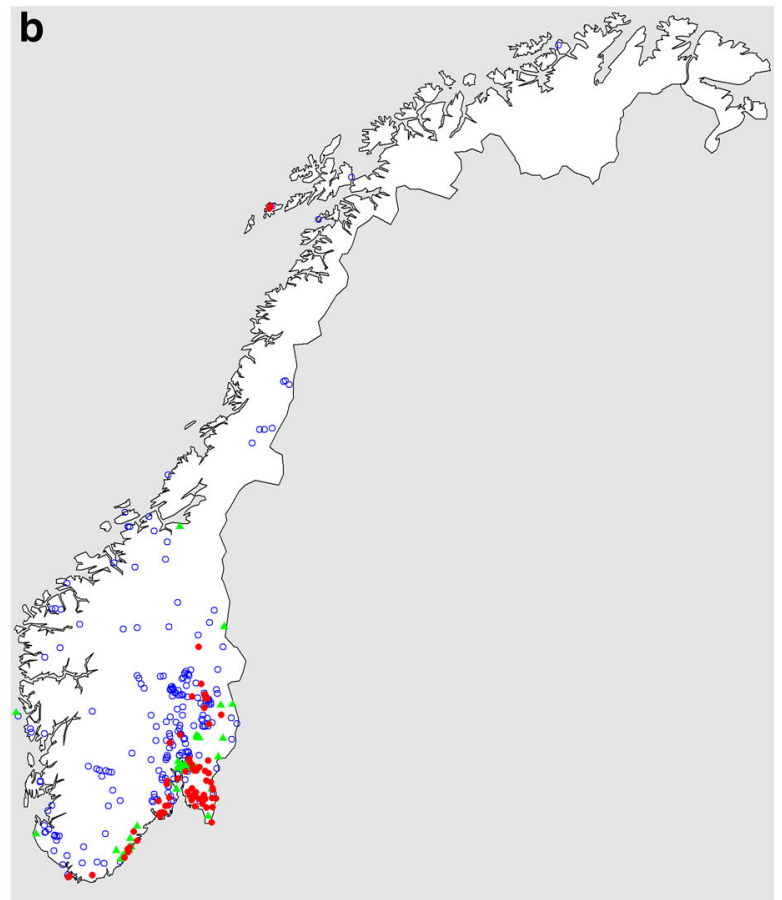

observations of $G$. semen during this time period, filled green triangles: other $G$. semen lakes observed regardless of these timespans (basically between 1998 and 2002))

amount of G. semen in general, constituting approx. $30-50 \%$ of the yearly average of total phytoplankton.

With the exception of Longumvannet, all lakes with sufficient data had significantly increased TOC values with time (Table 3). Colour had also increased significantly in the lakes which had sufficient data, except Rokosjøen where the increase was not significant, and Øyeren, the only lake with a significant decrease in colour (Table 3). Secchi depth decreased significantly in Isesjø, Langen and Lundebyvannet, non-significantly in Skjeklesjøen, and increased significantly in Rokosjøen, revealing an increasing trend in Gjølsjøen also, but this was not significant (Table 3). There has been significant increase in $\mathrm{pH}$ in Isesjø, Langen, Longumvannet and Rokosjøen (Table 3). The increase was not significant in Storsjøen (Table 3). Temperature was only available for six lakes, and revealed significant increase in Langen and Øyeren, and significant decrease in Isesjø (Table 3). The other lakes revealed a non-significant decrease (Øyeren) or increase (Lundebyvannet and Storsjøen) (Table 3). Total phosphorous increased 


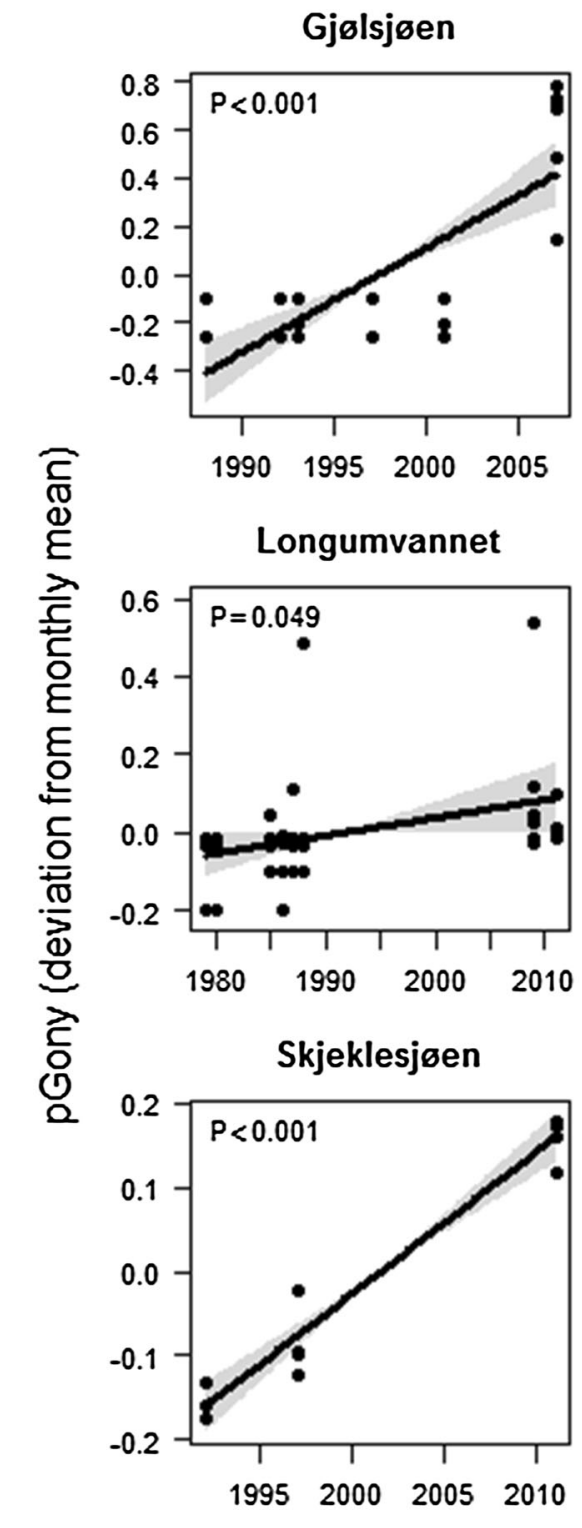

Gjølsjøen

Longumvannet

Fig. 4 Time trends in proportion of G. semen (pGony, \%) of total phytoplankton biomass for nine Norwegian lakes. PGony (vertical axis) has been season-adjusted according to a model with month as a factor, shown as the deviation from the long-

significantly in Isesjø and Langen, and decreased significantly in Øyeren (Table 3). The remainder of the lakes except Lundebyvannet revealed decreasing trends, but these were non-significant (Table 3). Total nitrogen levels significantly decreased in Langen and Longumvannet and increased in Skjeklesjøen (Table 3). No significant trends were shown for the remaining lakes (Table 3).
Isesjø



Lundebyvannet

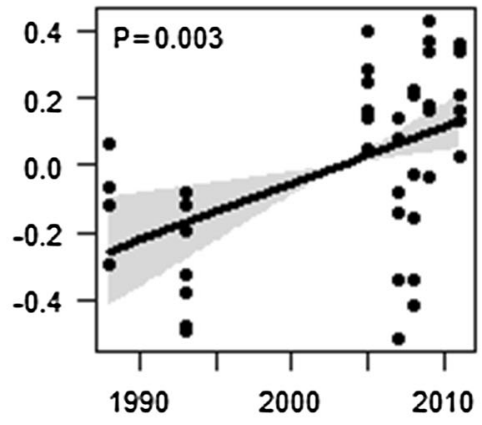

Storsjøen i Odalen

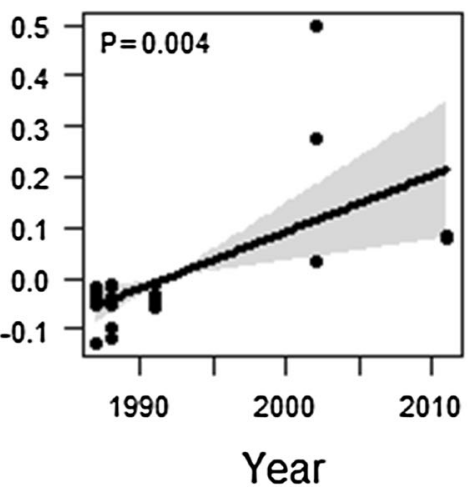

Langen

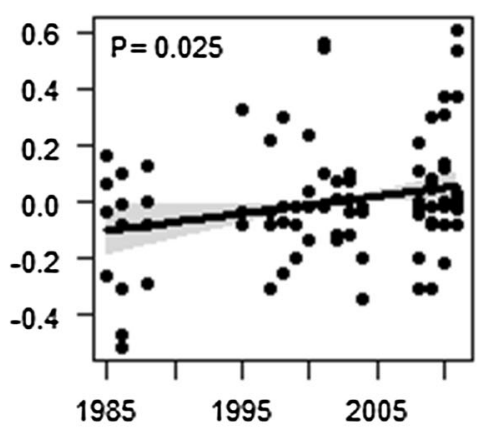

Rokosjøen

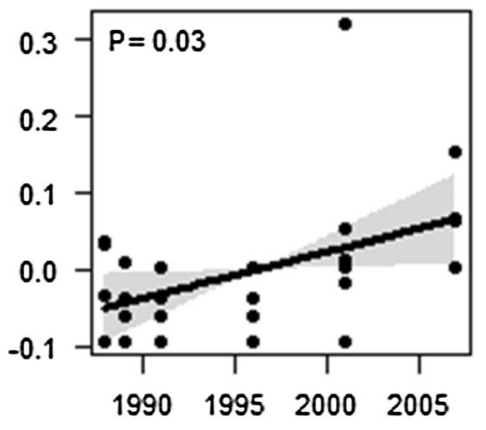

Øyeren

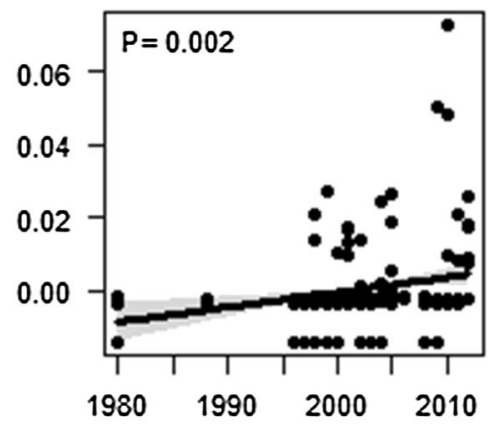

term means for each month. The statistical significance of the year effect (the $P$ value) is shown; significant time trends $=P<0.05$. Each dot represents one observed value

\section{Discussion}

Distribution

Our study shows that G. semen is at present widely distributed in the south-eastern part of Norway. Furthermore, its geographical distribution has clearly increased since 1988 , being recently also found in the 
Table 3 gives the $P$ values from the regressions on all available parameters

\begin{tabular}{|c|c|c|c|c|c|c|c|c|c|}
\hline Lakes & $\mathrm{BM}$ & PP & TOC & Colour & Secchi & $\mathrm{pH}$ & Temp & $\mathrm{TP}$ & $\mathrm{TN}$ \\
\hline Gjølsjøen & $<0.001+$ & $0.002+$ & $0.045+$ & $0.003+$ & $0.720+$ & $0.091+$ & & $0.066-$ & $0.942-$ \\
\hline Isesjø & $0.001+$ & $<0.001+$ & $<0.001+$ & $<0.001+$ & $<0.001-$ & $0.002+$ & $0.017-$ & $<0.001+$ & $0.174+$ \\
\hline Langen & $0.038+$ & $0.834+$ & $0.044+$ & & $<0.001-$ & $<0.001+$ & $<0.001+$ & $0.013+$ & $<0.001-$ \\
\hline Longumvannet & $0.007+$ & $<0.001+$ & $0.127+$ & $0.046+$ & & $0.023+$ & & $0.505-$ & $<0.001-$ \\
\hline Lundebyvannet & $0.079+$ & $0.034+$ & $<0.001+$ & $0.001+$ & $<0.001-$ & & $0.886-$ & $0.333+$ & $0.069+$ \\
\hline Rokosjøen & $0.055+$ & $0.154-$ & $<0.001+$ & $0.235+$ & $0.002+$ & $0.013+$ & $0.318-$ & $0.414-$ & $0.533+$ \\
\hline Skjeklesjøen & $0.030+$ & $0.017+$ & $<0.001+$ & $<0.001+$ & $0.079-$ & & & $0.160-$ & $<0.001+$ \\
\hline Storsjøen & $0.016+$ & $<0.001+$ & & $0.001+$ & & $0.283+$ & $0.100+$ & $0.466-$ & $0.325+$ \\
\hline Øyeren & $0.008+$ & $<0.001-$ & & $<0.001-$ & & & $<0.001+$ & $<0.001-$ & 0.527 \\
\hline
\end{tabular}

+ increase, - decrease, italic significant correlation $(P<0.05), B M G$. semen biomass, $P P$ total phytoplankton biomass

western part of the country (Horpestadvatnet, detected by qPCR). This supports our first hypothesis. Outside south-eastern Norway, G. semen has only been found in one lake in Trondheim (mid-Norway), one lake in Bergen (west), neither recently confirmed, and two lakes on Vestvågøy (north), the distribution reaching latitude 68. None of the lakes sampled in the middle parts of Norway through the additional sampling in 2012 contained G. semen; however, these lakes were sampled late (October) and only $25 \mathrm{ml}$ were investigated. There is therefore a possibility that it was too late in the season and also too cold, or that there are less than 1 G. semen cell present per $25 \mathrm{ml}$ water sample. Also, sampling time is influencing the results as we used surface samples on several occasions, and G. semen might be found in the deeper layers of the lake during parts of the day, and may not be present in samples during parts of the growth season (Eloranta \& Räike, 1995; Pithart \& Pechar, 1997).

The results by molecular methods suggest that $G$. semen may be present in more localities than what is currently registered by regular monitoring. The DNA based method is therefore useful for investigating lakes for presence of $G$. semen when it is present in low amounts. G. semen semen is closely related to Vacuolaria virescens (Lebret, 2012) and the two species can be difficult to distinguish by genetic methods. However, we managed to design primers that are species specific to Scandinavian freshwater Raphidophytes which did not give any signals when used on $V$. virescens cultures. We therefore feel confident that the results of this qPCR analysis are true detections of G. semen.
The distribution is most dominant in the southern counties close to Sweden (Hedmark, Østfold, Akershus and Oslo), seen in Fig. 2, with the number of lakes declining towards the north, middle and west. Already in 1982, G. semen dominated the late summer phytoplankton in $23 \%$ of investigated lakes in Østfold and Akershus county, probably present in many more (Bjørndalen \& Løvstad, 1984). Our study provides evidence that this distribution has strongly increased during the past decades and is further spreading west. The reason for the concentrated abundance in the counties close to Sweden may be partly because this area is warmer and has less precipitation than westNorway, causing east-Norwegian lakes to have greater nutrient loads and generally greater biomass and taxonomic richness of phytoplankton. Conversely, the alga may have invaded from Sweden relatively recently and may be in the process of distributing westwards thus colonizing further into Norway. This latter explanation is supported by previous studies showing that the colonizing of new lakes by, and invasion of, G. semen in Northern Europe is likely to be recent (past decades) (Lebret, 2012). The fact that G. semen was not reported in south-eastern Norway until 1980 and the current spreading towards central and western Norway suggest an invasion pattern from the east.

\section{Changes in biomass}

Already in 1988, an increase in both biomass and number of lakes containing G. semen had been observed in Norway (Hongve et al., 1988). Our study 
confirms this trend and shows that since 1988 the number of lakes containing this alga has continued to increase, and G. semen has also increased its proportion of the phytoplankton community. This corresponds with results from studies conducted in other Northern European countries where G. semen have also been observed in new lakes during the last decades whilst simultaneously increasing in biomass (Lepistö et al., 1994; Rengefors et al., 2012). In addition to these changes in distribution and biomass, our data show that the occurrences of incidents with mass occurrences $(\geq 1,000 \mu \mathrm{g} / \mathrm{l})$ of $G$. semen have been increasing since the 1980s. It should be noted that the lakes have various and inconsistent monitoring, thus this information is not based entirely on the same lakes every year. Additionally, typical G. semen lakes have not often been subject to monitoring, as the majority of monitored lakes have eutrophic conditions with increased risk of cyanobacteria blooms. G. semen is, in these lakes, often present in lower amounts, if at all, since it is known to thrive in conditions when cyanobacteria are not and is regarded an indicator of more mesotrophic conditions (Bjørndalen \& Løvstad, 1984; Hongve et al., 1988; Brettum \& Andersen, 2005). When it comes to mass occurrences, we see the greatest impact as the number of lakes gaining $G$. semen biomass $\geq 1,000 \mu \mathrm{g} / \mathrm{l}$ has increased, and a lesser impact by more samples having large biomass, especially the last decade (2001-2012). This is probably due to more comprehensive monitoring the latter years, both resulting in more lakes having been sampled, and also an increased number of samples having been examined, additionally when $G$. semen biomass is limited. Results from previous studies revealed May and October to be the main months of $G$. semen increase in Swedish lakes (Rengefors et al., 2012) and greater biomasses were found through a longer season than we observe in Norway (Rengefors et al., 2012; Lebret et al., 2012b). The pattern we observe in Norwegian lakes with large biomasses and blooms of G. semen occurring mainly in August and September can be a result of slow growth rate combined with warm water periods during the summer (Willén, 2003). It remains unclear whether the warm temperatures leading to increased G. semen biomasses are directly an effect of temperature on recruitment of cysts (Rengefors et al., 2012) and on growth rate in general, or if the effects are indirectly caused by increased temperatures leading to more intense stratification and better competitive conditions for $G$. semen which is capable of migrating to nutrient rich depths (Salonen \& Rosenberg, 2000).

There are large variations in biomass of G. semen in all the nine lakes investigated for biomass change, both between lakes and over years. These fluctuations can be caused by bloom incidents due to external factors like increased temperature, changes in precipitation, light conditions, nutrient levels and flushing of organic matter into the water, although the known extreme values are removed in these data. When looking at monitoring with short intervals between samples, there can be large differences from one week to the next. Therefore, sampling once a month or less will be a factor of uncertainty and sampling may occur during a sudden drop or peak in phytoplankton. However, the most recent guidelines on lake monitoring accepts monthly (May-October) as a minimum sampling interval, and the regression performed corrects for the differences among individual months, in order to minimize the possibility that seasonal fluctuations are influencing the results.

Our data show that the contribution of G. semen to the total phytoplankton biomass has increased significantly in eight of nine lakes, meaning that G. semen is showing a tendency to increasingly dominate the phytoplankton communities in Norwegian lakes. This increases support for our second hypothesis, as the pGony has increased also years after $G$. semen was first observed in five of the seven lakes where G. semen were already present at the start of the study period, and also pGony has increased in the two lakes where G. semen appeared later. The exception is Gjølsjøen where $G$. semen was not found in samples from the 1990s and 2001. However, even though an increase has occurred, the G. semen biomass and proportion is still neither large nor dominating in several of these lakes. Gjølsjøen did not host any G. semen during 1992-2001, and in Rokosjøen, Storsjøen and Øyeren, the yearly average of pGony is $0-5 \%$. Yet this increased to $48 \%$ at most (Storsjøen), however mainly remains much lower even in later years. In Longumvannet, relatively limited biomass of G. semen (yearly average of $188-313 \mu \mathrm{g} / \mathrm{l}$ ) was contributing as much as $15-28 \%$ to the total phytoplankton biomass. These results suggest that phytoplankton communities with low biomass, in general, can be vulnerable to the impact of this alga on the ecosystem even without occurrences of blooms or nuisance to the public. 
Due to lack of data for some of the lakes we did not aim for a comprehensive study on possible explanation factors to the observed changes in G. semen distribution or biomass. We do, however, try to couple the existing data to $G$. semen, focusing on the proportion of total phytoplankton biomass, in order to confirm whether the patterns seen in studies from other Scandinavian countries applies to Norway. TOC and colour values for Gjølsjøen and Lundebyvannet were on the border of being too scarce for a valid regression, however the results show significant increases for both parameters, and since this is in line with previous studies reporting DOC and water colour increases in Scandinavia (Monteith et al., 2007) and in Norwegian lakes (Hongve et al., 2004) during the past decades, we conclude that our regressions are plausible. The increase in pGony in eight of our studied lakes are to a certain degree coupled with a general increase in $G$. semen biomass, despite the fact that total phytoplankton biomass has also increased in some lakes, meaning that $G$. semen increases more than the remaining phytoplankton taxa. Only in Isesjø, $G$. semen has for some reason not been more successful than the remaining phytoplankton species. In Øyeren, total phytoplankton biomass has decreased since 1980, making the observed increasing trend in G. semen biomass and pGony even more interesting. Although never reaching large biomass in Øyeren, the results imply that $G$. semen is influencing the phytoplankton community more than other species present.

PGony has increased in these eight lakes despite a coinciding trend for higher $\mathrm{pH}$ for some lakes and no consistent pattern for all lakes concerning nutrients, suggesting these factors are not primary drivers of $G$. semen success and that $G$. semen thrives in a range of lake types. This is in agreement with previous studies finding that these parameters may explain the presence or absence of G. semen and define 'G. semen lakes', and therefore may be influencing growth and success on some level, but they do not drive or control the abundance to a large degree (Cronberg et al., 1988; Findlay et al., 2005; Rengefors et al., 2012).

In some of the lakes, increases in pGony can be related to coinciding or preceding ascending trends in TOC, water colour and loss of visibility. These factors are often linked to each other, TOC leading to higher water colour and in turn this leading to loss of visibility, the latter potentially also influenced by the amount of phytoplankton in the water. In addition, an increase in TOC will also increase the concentration of total phosphorus (Hanson et al., 2003). Rengefors et al. (2008) showed that G. semen grew better with the addition of fulvic acid, a common component of humic matter, supporting other studies that claim $G$. semen to prefer humic lakes with high colour (Bjørndalen \& Løvstad, 1984; Hongve et al., 1988; Brettum \& Andersen, 2005). Additionally, reduced visibility could enhance competition success and growth of $G$. semen through enhanced stratification, as it migrates in the water column avoiding the greatest light intensities (Eloranta \& Räike, 1995; Salonen \& Rosenberg, 2000). Although our study reveals a relationship between TOC, colour, visibility and pGony for some lakes, this cannot explain why $G$. semen has not increased more than the remaining phytoplankton in Isesjø despite the same patterns in these factors. Additionally, the changes in Øyeren, where pGony has increased, while colour has decreased (TOC and Secchi not available), does not conform to the relationship between lake colour and G. semen biomass observed. However, both Isesjø and $\varnothing y e r e n$ are large lakes and Øyeren has a short turnover time, which might explain why they are not behaving like other lakes in this study. The common explanatory factor in our study for these two lakes is temperature, significantly declining in Isesjø and rising in Øyeren. According to a previous study by Rengefors et al. (2012), rise in temperature is connected to an increase in abundance and biomass of G. semen in Swedish lakes over the past decades. Rengefors et al. (2012) however, used biomass as a measurement and not biomass proportion of the total phytoplankton, as we have done in this study. Hence, Isesjø should have increased in temperature coupled to the increase in $G$. semen biomass if temperature was the only influence. It is therefore likely that both temperature and other factors are controlling the growth and inhibiting success of G. semen. Previous studies suggest that the presence of and grazing from certain zooplankton might influence the occurrence and growth success of G. semen (Hansson, 1996; Findlay et al., 2005; Lebret et al., 2012a; Johansson et al., 2013b), However, we did not have data for this in our study.

In addition to directly influencing cyst germination and growth rate (Rengefors et al., 2012), lake surface temperatures affect the intensity of thermal stratification, this also being a competitive advantage for an alga like $G$. semen which can migrate in the water 
column and utilize nutrients in the hypolimnion, and thus avoiding grazing (Salonen \& Rosenberg, 2000). Temperature also has increased in Langen and Øyeren. While TOC and Secchi depth were not available for Øyeren, both TP and colour declined during this time period. The upward trend in pGony regardless of this suggests temperature to be the most probable explanation in our study.

\section{Conclusion}

We find that in Norwegian lakes, G. semen is following the same patterns as seen in other Scandinavian and Northern European countries and has been increasing in both geographical distribution, number of lakes and the proportion it contributes to the total phytoplankton biomass within lakes, since the 1980s. The frequency and distribution of blooms have also increased. The occurrence is predominately in the south-eastern parts of Norway closest to Sweden, from there spreading towards the west and south. The distribution pattern is possibly caused by spreading from Sweden combined with conditions preferred by $G$. semen in this part of the country. Our results indicate that lake surface temperature is a possible influencing factor for the within-lake increase in phytoplankton dominance over time, and TOC, colour and Secchi depth appear to be important in some lakes. However, we still cannot rule out other factors to be controlling the success. If the trends as suggested by our results continue, future climate conditions are plausible to lead to even more G. semen occurrence and abundance. More frequent blooms will be of nuisance for swimmers, possibly leading to economic consequences for local authorities, but may also cause problems with monitoring sampling, classification of water quality and drinking water supplies. Thus, additional contributing factors which might influence this alga are important to study further.

Acknowledgements We thank several colleagues at NIVA for gathering samples for us during their field work and also employees at local governments and other volunteers for sampling some of their nearby lakes. We thank Karin Rengefors and Karen Lebret at the University in Lund, Sweden for good advice and initial help with primers, and Jonas Persson at NIVA for the excellent plotted maps. Also thanks to Kate Hawley at NIVA for helping with lake coordinates and the English language of the paper. This study was supported with funding from the Research Council of
Norway (RCN) through NIVA's Strategic Institute Initiative "Climate effects from Mountains to Fjords" (Contract No. 208279) and through the RCN funded project ECCO (contract no. 224779).

Open Access This article is distributed under the terms of the Creative Commons Attribution License which permits any use, distribution, and reproduction in any medium, provided the original author(s) and the source are credited.

\section{References}

Angeler, D. G., C. Trigal, S. Drakare, R. K. Johnson \& W. Goedkoop, 2010. Identifying resilience mechanisms to recurrent ecosystem perturbations. Oecologia 164: 231-241.

Berge, D., 1991. Forurensningsutviklingen i drikkevannskilden Oppegårdstjernet i Frogn kommune - Årsakssammenheng. (Pollution development in the drinking water source Lake Oppegårdstjern, Frogn - Causes). NIVA-report OR-2533, Norwegian Institute for Water Research: 15 (In Norwegian).

Bjørndalen, K., 1982. Gonyostomum semen - en ny problemalge? (Gonyostomum semen - a new nuisance alga?). Limnos 2: 4.

Bjørndalen, K. \& Ø. Løvstad, 1984. En regionalundersøkelse av innsjøer i Østfold. Eutrofiering og problemalger. (A regional survey of lakes in Østfold county. Eutrophication and nuisance algae.) VANN 1:10 (In Norwegian).

Brettum, P. \& T. Andersen, 2005. The use of phytoplankton as indicators of water quality. NIVA-report 4818-2005, Norwegian Institute for Water Research: 33pp.

Cronberg, G., G. Lindmark \& S. Björk, 1988. Mass development of the flagellate Gonyostomum semen (Raphidophyta) in Swedish forest lakes - an effect of acidification? Hydrobiologia 161: 217-236.

Directorate group, Water Framework Directive. 2013. Veileder 02:2013 Klassifisering av miljøtilstand i vann. Direktoratsgruppa for gjennomføringen av vanndirektivet. (Guide 02:2013 Classification of environmental condition in water, Directorate Group for the implementation of the Water Framework Directive.) (In Norwegian).

Eloranta, P. \& A. Räike, 1995. Light as a factor affecting the vertical distribution of Gonyostomum semen (Ehr.) Diesing (Raphidophyceae) in lakes. Aqua Fennica 25: 15-22.

Figueroa, R. \& K. Rengefors, 2006. Life cycle and sexuality of the freshwater Raphidophyte Gonyostomum semen (Raphidophyceae). Journal of Phycology 42: 859-871.

Findlay, D. L., M. J. Paterson, L. L. Hendzel \& H. J. Kling, 2005. Factors influencing Gonyostomum semen blooms in a small boreal reservoir lake. Hydrobiologia 533: 243-252.

Haande, S., H. Edvardsen, T. Eriksen, M. Kile, C. H. C. Hagman, H. Borch, R. Brænden, J. F. Arnesen \& L. Raudsandmoen, 2012. Tilstandsklassifisering av vannforekomster i Vannområde Glomma Sør for Øyeren (2011) i henhold til vannforskriften. (Classification of state of water bodies in the Glomma Sør river basin district.) NIVA-report 6406-2012, Norwegian Institute for Water Research: 152 (In Norwegian). 
Hanson, P. C., D. L. Bade, S. R. Carpenter \& T. K. Kratz, 2003. Lake metabolism: relationships with dissolved organic carbon and phosphorous. Limnology and Oceanography 48(3): 8.

Hansson, L. A., 1996. Behavioural response in plants: adjustment in algal recruitment induced by herbivores. Proceedings of the Royal Society of London 263: 1241-1244.

Hertzberg, J., Ø. Løvstad \& K. Bjørndalen, 1989. Vassdragsovervåking i Hobølvassdraget i Akershus 1985-1987. (Monitoring of the Hobøl water body, Akershus county 1985-1987.) County government in Oslo and Akershus, Department of Environment, Vol. 3/89:33 (In Norwegian).

Hongve, D., Ø. Løvstad \& K. Bjørndalen, 1988. Gonyostomum semen - a new nuisance to bathers in Norwegian lakes. Verhandlungen des Internationalen Verein Limnologie 23: 430-434.

Hongve, D., G. Riise \& J. F. Kristiansen, 2004. Increased colour and organic acid concentrations in Norwegian forest lakes and drinking water - a result of increased precipitation? Aquatic Sciences 66(2): 231-238.

Johansson, K. S. L., C. Trigal, T. Vrede \& R. K. Johnson, 2013a. Community structure in boreal lakes with recurring blooms of the nuisance flagellate Gonyostomum semen. Aquatic Sciences 75(3): 447-455.

Johansson, K. S. L., T. Vrede, K. Lebret \& R. K. Johnson, 2013b. Zooplankton feeding on the nuisance flagellate Gonyostomum semen. PLoS One 8(5): e62557.

Lebret, K., 2012. A phytoplankton invasion: Population genetics, phylogeography, and invasion success of Gonyostomum semen. Paper III. Doctoral thesis, Lund University.

Lebret, K., M. F. Fernandez, C. H. C. Hagman, K. Rengefors \& L. A. Hansson, 2012a. Grazing resistance allows bloom formation and may explain invasion success of Gonyostomum semen. Limnology and Oceanography 57(3): 727-734.

Lebret, K., E. S. Kritzberg, R. Figueroa \& K. Rengefors, 2012 b. Genetic diversity within and genetic differentiation between blooms of a microalgal species. Environmental Microbiology 14(9): 2395-2404.

Lepistö, L., S. Antikainen \& J. Kivinen, 1994. The occurrence of Gonyostomum semen (Ehr.) Diesing in Finnish lakes. Hydrobiologia 273: 1-8.
Monteith, D. T., J. L. Stoddard, C. D. Evans, H. A. de Wit, M. Forsius, T. Høgåsen, A. Wilander, B. L. Skjelkvåle, D. S. Jeffries, J. Vuorenmaa, B. Keller, J. Kopácek \& J. Vesely, 2007. Dissolved organic carbon trends resulting from changes in atmospheric deposition chemistry. Nature 450: 5.

Pithart, D. \& L. Pechar, 1997. Summer blooms of raphidophyte Gonyostomum semen and its diurnal vertical migration in a floodplain pool. Algological Studies 85: 119-133.

Rengefors, K., C. Pålsson, L. A. Hansson \& L. Heiberg, 2008. Cell lysis of competitors and osmotrophy enhance growth of the bloom-forming alga Gonyostomum semen. Aquatic Microbial Ecology 51: 87-96.

Rengefors, K., G. A. Weyhenmeyer \& I. Bloch, 2012. Temperature as a driver for the expansion of the microalga Gonyostomum semen in Swedish lakes. Harmful Algae 18: 65-73.

Salonen, K. \& M. Rosenberg, 2000. Advantages from diel vertical migration can explain the dominance of Gonyostomum semen (Raphidophyceae) in a small, steeplystratified humic lake. Journal of Plankton Research 22(10): 1841-1853.

Sörensen, I., 1954. Gonyostomum semen (Ehrenb.) Diesing - en vattenorganism av teoretiskt och praktickt intresse. (Gonyostomum semen (Ehrenb.) Diesing - a water organism of theoretical and practical interest.) Svensk Faunistisk Revy 2:6 (In Swedish).

Trigal, C., W. Goedkoop \& R. K. Johnson, 2011. Changes in phytoplankton, benthic invertebrate and fish assemblages of boreal lakes following invasion by Gonyostomum semen. Freshwater Biology 56(10): 1937-1948.

Utermöhl, H., 1958. Zür Vervollkommung der quantitativen Phytoplankton-Methodik. (Perfectioning quantitative phytoplankton methodology.) Mitteilungen Internationale Vereiningung fuer Theoretische und Angewandte Limnologie 9:1-38 (In German).

Willén, E., 2003. Dominance patterns of planktonic algae in Swedish forest lakes. Hydrobiologia 502: 315-324. 